
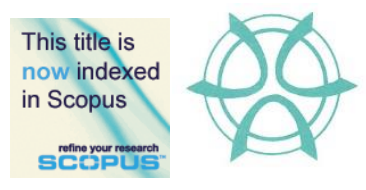

PLANNING MALAYSIA:

Journal of the Malaysian Institute of Planners

VOLUME 18 ISSUE 1 (2020), Page 24 - 34

\title{
AN ASSESSMENT OF HOUSING AFFORDABILITY INDEX AT DISTRICTS LEVEL IN KELANTAN
}

\author{
Mariana Mohamed Osman', Farah Eleena Zainudin², Noor Suzilawati \\ Rabe $^{3}$, Mizan Hitam ${ }^{4} \&$ Muhammad Faris Abdullah ${ }^{5}$ \\ ${ }^{1,2,3,5}$ Kulliyah of Architecture and Environmental Design \\ INTERNATIONAL ISLAMIC UNIVERSITY OF MALAYSIA \\ ${ }^{4}$ Faculty of Architecture, Planning and Surveying \\ UNIVERSITI TEKNOLOGI MARA
}

\begin{abstract}
The purpose of this paper is to assess the housing affordability level in every district in Kelantan. The goal of this study is to determine the affordability level and the affordable housing price in every district in Kelantan. In order to determine the housing affordability level, the Price-to-Income Ratio approach or known as median multiple is used in this study. The study found that the overall affordable leve in Kelantan from 2012, 2014 to 2016 has increased from 4.5 to 4.8 to 5.4 which clearly showed the level worsen over the years. In term of afforadablee housing price, the Kelantan median house price for 2016 was RM199,900 but using median multiple calculation using the income data, the maximum affordable house price should be within RM 110,844, which clearly showed that the current housing prices is severely unafforable for Kelantan State.
\end{abstract}

Keyword: housing affordability index, median house price, median income, affordable housing price, median multiple 
PLANNING MALAYSIA

Journal of the Malaysia Institute of Planners (2020)

\section{INTRODUCTION}

Shelter is an essential need according to the hierarchy Abraham Maslow (1943). According to the Australian Council of Social Service (ACOSS), access to housing that is affordable is essential for individual, family and community wellbeing (ACOSS 2008). According to Khazanah Research Institute, KRI (2017) and Bank Negara Malaysia (2019), a house is considered affordable when the median price of housing market is three times the gross annual household income (Star Online, 2019). The National Housing Policy 2018- 2025 highlighted that the main issue faced by Malaysian, is the unaffordable housing market where the many Malaysian are unable to purchase a house offered in the market due to its high prices (News Straits Times, 2018). In Malaysia, the affordable house price is within the range of RM165,000 to RM242,000 based on the annual median income of RM55,0020 (Bank Negara Malaysia, 2017). The median multiple calculation shows that Malaysia housing price currently is at 4.4 which is highly unaffordable.

\section{OBJECTIVES OF THE STUDY}

According to KRI Report (2015), all states in Malaysia indicates higher percentage of home ownership in rural area as compared to the urban area. This is due to land price in the rural are chaper compare to urban area and land value in urban area tend to be expensive due to economic activity centred in this area. Additionally, Mohamed Osman et al. (2017) stated that the shortage of affordable housing was critical and the level of income worsen over 2012, 2014, and 2016. Thus, this study intends to assess housing affordability index using data produced by the Department of Statistic (2012, 2014 \& 2016) and NAPIC (2012, 2014 \& 2016). The objectives of this paper are to:

i. To examine the housing affordability index for every district in Kelantan for the year 2012, 2014 and 2016

ii. To propose the maximum affordable housing price for each district using the price to income ratio approach

iii. To provide recommendations on the affordable housing price at districts level in Kelantan

\section{LITERATURE REVIEW}

Housing affordability is an important agenda in Malaysia based on the National Housing Policy 2018-2025, nationally. The term housing affordability became popular in the past two decades, replacing 'housing need' which is at the center of the debate in the year 2000 in providing adequate housing for all. According to AHURI (2004) "the affordability of housing" refers to the ability of households to meet housing costs, while maintaining the ability to cover other basic living 
Mariana Mohamed Osman, Farah Eleena Zainudin, Noor Suzilawati Rabe, Mizan Hitam \& Muhammad Faris Abdullah

An Assessment of Housing Affordability Index at Districts Level in Kelantan

costs. Shuid (2016) mentions that the affordable housing is also defined as what is appropriate in terms of quality and location other than price. In Malaysia, the percentage of home ownership is $69.1 \%$ in the urban area and $81.2 \%$ in the rural area. KRI report in 2015 and 2017 identified that housing affordability level in Malaysia has worsen over the years and the purchasing power among Malaysian has also reduced further.

Affordability can be measured through price-to-income ratio, more commonly known as the 'median-multiple' developed in 1988 by the United Nations Centre for Human Settlement (UNCHS) and the World Bank under the Housing Indicators Program. The median multiple is based on the assumption that as housing prices become higher relative to incomes, a smaller proportion of households can afford to buy houses, other factors held constant.

\section{Metric Measurement for Housing Affordability}

\section{Price- to Income Ratio}

This study uses the approach of Price to Income Ratio (PIR) to measure housing affordability. PIR is the method that shows the ratio based on the median housing prices over the annual household income. This approach was developed in 1988 by the United Nations Centre for Human Settlement (UNCHS) and the World Bank under the Housing Indicators Program (KRI Report, 2015). The advantage of this approach is to know the households' greater ability to pay for housing and also to compare measures of prices and incomes (Fox \& Finlay, 2012). A formula of PIR as illustrates in Figure 1:

$$
\text { PIR }=\frac{\text { Median house price }}{\text { Annual Median Income }}
$$

Figure 1 Formula PIR Approach Source: Norazmawati (2015)

Demographia International Housing Affordability Survey (2004) also had introduced the housing affordability rating. Table 1 represents the affordability categories.

Table 1 Housing Affordability Categories

\begin{tabular}{cc}
\hline Rating & Median Multiple \\
\hline Severely Unaffordable & 5.1 and above \\
\hline Seriously Unaffordable & $4.1-5.0$ \\
\hline Moderately Unaffordable & $3.1-4.0$ \\
\hline Affordable & 3.0 and below \\
\hline Source: Khazanah Research Institute Report (2015)
\end{tabular}




\section{Median multiple Three}

The three times median multiple is considered as an appropriate threshold to calculate housing affordability cited by Housing Buyers' Association and in the $11^{\text {th }}$ Malaysia Plan (KRI, 2015). Thus, to forecast the affordable maximum price is by the calculation of annual median income multiple by three.

The factors influencing housing affordability of residents are housing price, household income, housing demand and types of housing. The relationship between house price and income level reflect the consequences on the housing affordability of the people in purchasing a house. Research suggest that housing prices reduces the housing affordability.

Table 3: Factors determine housing affordability

\begin{tabular}{ll}
\hline Factors & Literature review \\
\hline $\begin{array}{l}\text { Housing } \\
\text { prices }\end{array}$ & $\begin{array}{l}\text { The dynamic behavior of housing price can influence cyclic patterns in the } \\
\text { housing market3 } \\
\text { Previous studies investigate the escalating housing affordability problem } \\
\text { resulting from the bubble-like behavior of house prices, } 4\end{array}$ \\
\hline $\begin{array}{l}\text { Househ } \\
\text { old }\end{array}$ & $\begin{array}{l}\text { Purchase affordability considers the ability of a household to borrow } \\
\text { enough funds to purchase a house, while repayment affordability considers } \\
\text { the ability of a household to repay the mortgage } 5\end{array}$ \\
& $\begin{array}{l}\text { that households encounter a housing affordability problem when they pay } \\
\text { more than a certain proportion of their income to obtain suitable housing.6 }\end{array}$ \\
\hline
\end{tabular}

\section{RESEARCH METHODOLOGY}

\section{Study Area}

The study area is in the state of Kelantan where the state is located in the northeastern part of Peninsular Malaysia with total area of 5, 713 square miles or $11.2 \%$ of the total area of Peninsular Malaysia. Kelantan is bounded to Thailand in the north, South China Sea in the northeast, Terengganu in the east, Pahang in the south and Perak in the west. Kelantan consists of 10 districts namely Bachok, Kota Bharu, Machang, Pasir Mas, Pasir Puteh, Tanah Merah, Tumpat, Gua Musang, Kuala Krai and Jeli.

According to Department of Statistic Malaysia (2017) the main economic activities in Kelantan are services (66.4\%) and agriculture (24.6\%). The Gross Domestic Product (GDP) per capita in 2016- 2017 shows that Kelantan is at the lowest rank among other states in Malaysia. However, in terms of economic growth in services, manufacturing as well as agriculture sector, data 
Mariana Mohamed Osman, Farah Eleena Zainudin, Noor Suzilawati Rabe, Mizan Hitam \& Muhammad Faris Abdullah

An Assessment of Housing Affordability Index at Districts Level in Kelantan

from Department of Statistic (2018) showed an improvement or better economic growth from 2016 to 2018.

Despite the encouraging activities, Kelantan ranked last amongst other states in terms of urbanisation in Malaysia and report form Khazanah Research Institute (2016) stated that Kelantan only portrayed $42.4 \%$ of urbanisation level. Additionally, in 2016 Kelantan was the third highest state with poverty recorded at $0.4 \%$. In terms of annual median income, residents in Kelantan received the lowest compared to other states in Malaysia which amounted RM 36,948 in 2016 (NAPIC, 2017). This is the reason why the state of Kelantan was chosen as a case study.

\section{Data Collection and Analysis Method}

This study only analyses the secondary data from National Property Information Centre (NAPIC) and Department of Statistic (DOS) as well as trusted sources for instance journal article, published reports, websites and books. The study will used descriptive analysis with combination of (i) graphical description such as graphs, (ii) tabulated description and (iii) statistical commentary which will be part of the discussion in this paper.

\section{ANALYSIS AND FINDINGS}

\section{Comparison of Housing Affordability Index in Districts Level in Kelantan}

Table 2 Comparison of Annual Median Income and Median House Price in 2012, 2014 And 2016 in Districts Level of Kelantan

\begin{tabular}{|c|c|c|c|c|c|c|}
\hline \multirow[b]{2}{*}{ Districts } & \multicolumn{2}{|c|}{2012} & \multicolumn{2}{|r|}{2014} & \multicolumn{2}{|c|}{2016} \\
\hline & $\begin{array}{c}\text { Annual } \\
\text { Median } \\
\text { Income } \\
\text { (RM) }\end{array}$ & $\begin{array}{c}\text { Median } \\
\text { House } \\
\text { Prices } \\
(\mathrm{RM})\end{array}$ & $\begin{array}{c}\text { Annual } \\
\text { Median } \\
\text { Income } \\
\text { (RM) }\end{array}$ & $\begin{array}{c}\text { Median } \\
\text { House } \\
\text { Prices } \\
(\mathrm{RM})\end{array}$ & $\begin{array}{c}\text { Annual } \\
\text { Median } \\
\text { Income } \\
\text { (RM) }\end{array}$ & $\begin{array}{c}\text { Median } \\
\text { House } \\
\text { Prices } \\
\text { (RM) }\end{array}$ \\
\hline Bachok & 25,920 & 110,000 & 30,276 & 210,000 & 35,196 & 250,000 \\
\hline Kota Bharu & 31,068 & 210,000 & 38,820 & 211,250 & 44,124 & 240,000 \\
\hline Machang & 30,372 & 116,500 & 32,592 & 178,500 & 35,472 & 150,000 \\
\hline Pasir Mas & 23,136 & 133,760 & 26,328 & 165,000 & 30,516 & 205,000 \\
\hline Pasir Puteh & 25,116 & 122,500 & 29,052 & 55,000 & 34,740 & 187,000 \\
\hline Tanah Merah & 26,160 & 93,000 & 32,964 & 105,000 & 36,252 & 150,000 \\
\hline Tumpat & 27,168 & 193,500 & 33,288 & 180,000 & 37,260 & 280,000 \\
\hline Gua Musang & 29,952 & 94,000 & 31,884 & 115,000 & 33,816 & 148,690 \\
\hline Kuala Krai & 20,928 & 91,500 & 28,920 & 127,500 & 30,492 & 183,350 \\
\hline Jeli & 21,636 & 108,000 & 26,412 & 111,000 & 28,524 & 268,000 \\
\hline Kelantan & 27,312 & 122,500 & 32,592 & 157,740 & 36,948 & 199,900 \\
\hline
\end{tabular}


PLANNING MALAYSIA

Journal of the Malaysia Institute of Planners (2020)

Table 3 Percentage Increase and Decrease in Median Income and Median House Price

\begin{tabular}{lcccc}
\hline \multirow{2}{*}{ Districts } & \multicolumn{2}{c}{2014} & \multicolumn{2}{c}{2016} \\
\cline { 2 - 5 } & $\begin{array}{c}\text { Median Income } \\
\%\end{array}$ & $\begin{array}{c}\text { Median House } \\
\text { Price } \%\end{array}$ & $\begin{array}{c}\text { Median Income } \\
\%\end{array}$ & $\begin{array}{c}\text { Median House } \\
\text { Price \% }\end{array}$ \\
\hline Bachok & 16.81 & 90.91 & 16.25 & 19.05 \\
\hline Kota Bharu & 24.95 & 0.60 & 13.66 & 13.61 \\
\hline Machang & 7.31 & 53.22 & 8.84 & -15.97 \\
\hline Pasir Mas & 13.80 & 23.36 & 15.91 & 24.24 \\
\hline Pasir Puteh & 15.67 & -55.10 & 19.58 & 240.00 \\
\hline Tanah Merah & 26.01 & 12.90 & 9.97 & 42.86 \\
\hline Tumpat & 22.53 & -6.98 & 11.93 & 55.56 \\
\hline Gua Musang & 6.45 & 22.34 & 6.06 & 29.30 \\
\hline Kuala Krai & 38.19 & 39.34 & 5.44 & 43.80 \\
\hline Jeli & 22.07 & 2.78 & 8.00 & 141.44 \\
\hline Kelantan & $\mathbf{1 9 . 3 3}$ & $\mathbf{2 8 . 7 7}$ & $\mathbf{1 3 . 3 7}$ & $\mathbf{2 6 . 7 3}$ \\
\hline \multicolumn{5}{r}{ Source: NAPIC $(2016)$} \\
\end{tabular}

Table 2 shows the annual median income and median house price for the year 2012, 2014 and 2016 in every district in Kelantan. Based on table 2, the annual median household income in every district increased over the year 2012, 2014 and 2016. In term of housing prices, the increase of median house price can be seen in majority of the districts except in Pasir Puteh and Tumpat between 2012 and 2014.

Table 3 indicates the changes in the percentage of annual median income and median house price in the year 2014 and 2016. In 2014, the largest percentage increase in annual median income was in Kuala Krai with $38.19 \%$ increase which is similar with increased in housing price (39.34\%). That is why the level of affordability remains the same (figure 2 ). For the median house price (2014), the largest percentage increase (90.19\%) was in Bachok while the median income only increased by $16.81 \%$. In 2016 , the biggest percentage increase in median income and median house price was in the district of Pasir Puteh but this did not guarantee that the houses remained at 'affordable'range. This is because the percentage increase in median income was $19.58 \%$ but the increased on the median house price was nearly $240 \%$. 
Mariana Mohamed Osman, Farah Eleena Zainudin, Noor Suzilawati Rabe, Mizan Hitam \& Muhammad Faris Abdullah

An Assessment of Housing Affordability Index at Districts Level in Kelantan

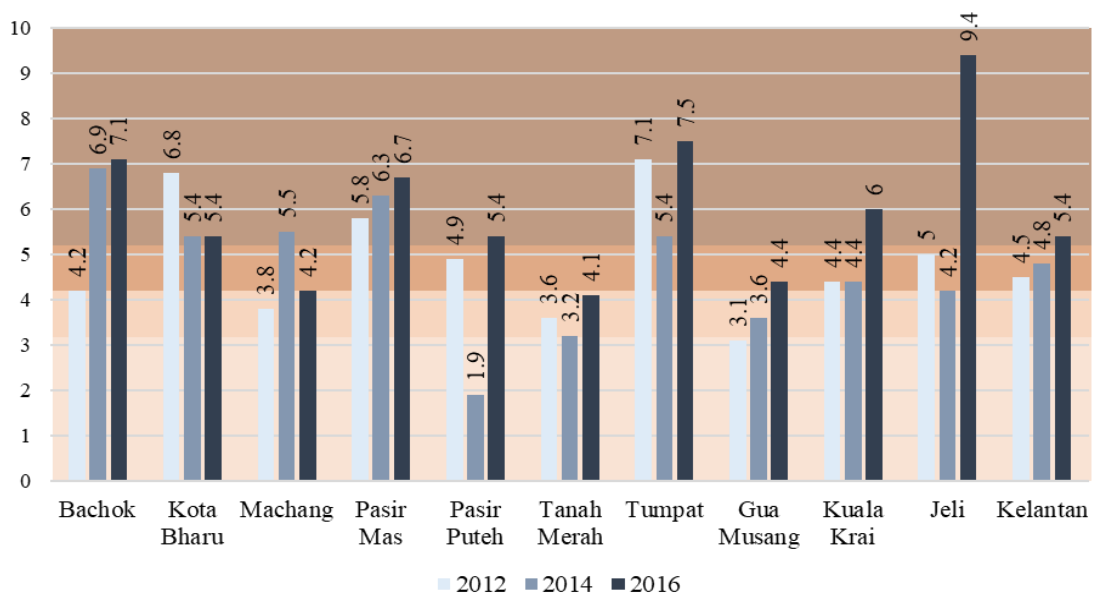

Figure 2 Housing Affordability Index in Every Districts in Kelantan for Year 2012, 2014 And 2016

Source: Author's Calculation based on NAPIC (2016)

Figure 2 illustrates the housing affordability index in every district in Kelantan. In general, the median house price in Kelantan exceeds the three times median annual household income threshold which showed that houses in all districts in Kelantan were not affordable. The index in Kelantan worsen from 2012 to 2016. In 2012, the index was at 4.5 and worsen to 4.8 in 2014 whereby the index for both years were at 'seriously unaffordable'. In 2016, the affordability index for Kelantan state continued to worsen to 5.4 which is extremely unaffordable. The reason is due to the house price rise much faster than income/wages (Tejvan Pettinger, 2019), thus making housing become more unaffordable (Mohamed Osman, et al. 2017).

The district of Jeli having the worse affordability level for the year 2016 where the index increases from 4.3 (2014) to 9.4 in 2016. Based on DOS data, the household income increased by $8 \%$ but the increased of median housing price were $141.44 \%$. The rapid increased of housing prices made the affordable level to be 'extremely unaffordable' with index 9.4. However, in 2016, the districts of Machang and Kota Bahru affordability index was better than 2014 where the index reduced from 5.5 to 4.2 while the later district index remained at 5.4. This is because the median income increased at higher rate as compare to the median housing prices. The overall affroability index for Kelantan state worsens over the year $(2012,2014$ and 2016) where the indexed worsen from 4.4 - seriously unaffordable (2012) to 4.8 - seriously unaffordable (2014) and further worsen to 5.4 - severely unaffordable (2016). This clearly showed that the income of the local household is low and unable to cover the housing prices within the state. 


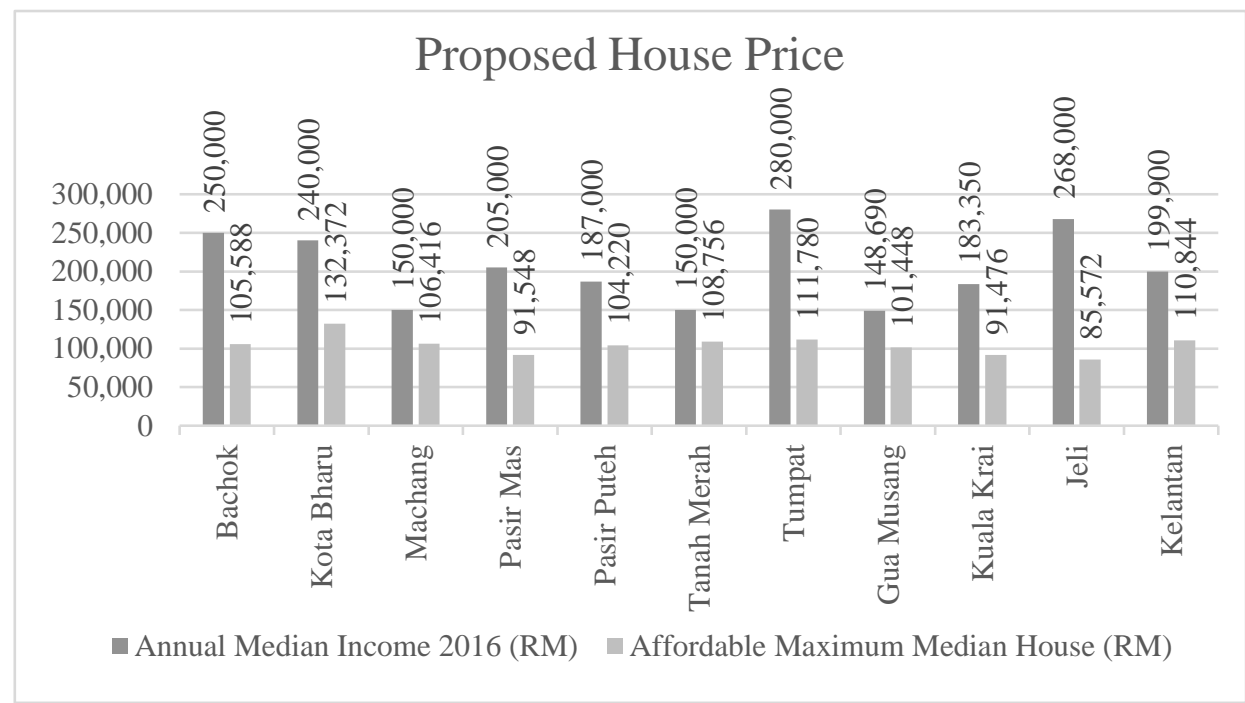

Figure 3 Maximum Affordable House Price in Every Districts Source: Author's Calculation based on NAPIC (2016)

Figure 3 portrays the affordable housing prices within the districts in Kelantan maximum median house price based on housing affordability index ratio 3.0. For the whole Kelantan, the median house price for 2016 was RM 199,900 but based on the median multiple three, the affordable house price was RM 110,844 with the difference of $44.6 \%$. Among all the districts, the largest gap is in Jeli with median house price for 2016 was RM 268,000 and the affordable house price was at RM 85,572. Thus, the price gap was RM 182, 428 (68\%). This is followed by Tumpat and Bachok with the price gap of RM 168, 220 (60.1\%) and RM 144, $412(57.8 \%)$ respectively. Whilst, the lowest house price gap is in Tanah Merah which was RM 41,244 (27.5\%). The prevailing market prices in key urban employment district were beyond the means of households, with varying degrees of severity across locations and districts.

Table 4 shows the estimation of the range of afordable house price based on income range prepared by the Department of Statistic and Bank Negara Malaysia in 2016. The table used both the Housing Cost Burden approach for the lower house price range and Residual Income approach for the upper price range. The lower house price in the range is calculated based on the Housing Cost Burden approach, in which a house is deemed affordable if the monthly housing loan installment does not exceed 30\% of household net monthly income (after statutory deductions). Estimates are based on interest rate of $4.5 \%$ and 35-year loan tenure. The upper house price in the range is calculated based on the Residual Income approach, which takes into account statutory deductions, basic expenditures and other debt obligations, and with the assumptions of loan-to- 
Mariana Mohamed Osman, Farah Eleena Zainudin, Noor Suzilawati Rabe, Mizan Hitam \& Muhammad Faris Abdullah

An Assessment of Housing Affordability Index at Districts Level in Kelantan

value ratio of $90 \%$, interest rate of $4.5 \%$ and 35-year loan tenure. (Bank Negara, 2016)

Table 4 Maximum Affordable House Price in Every Districts

\begin{tabular}{rr}
\hline Household Income Range (RM) & Maximum Affordable House Price (RM) \\
\hline$\leq 1,999$ & $112,200-124,700$ \\
\hline $2,000-3,999$ & $222,150-247,200$ \\
\hline $4,000-5,999$ & $318,600-354,100$ \\
\hline $6,000-7,999$ & $408,300-453,600$ \\
\hline $8,000-9,999$ & $493,500-556,100$ \\
\hline $10,000-14,999$ & $699,560-777,600$ \\
\hline Source: Department of Statistics Malaysia (2016) and Bank Negara Malaysia (2016)
\end{tabular}

However, in this study, the researcher used the price to income ratio approach and to calculate the maximum affordable house price, the annual median income household is multiple by 3.0. Table 5 indicates the proposed house price for every district. The result portrays that the affordable house price using house price to income ratio approach estimated lower housing prices compared to the approach of Housing Cost Burden and Residual Income Approach. For example the capability of the residents in Jeli with median income of RM 2,377 per month is to purchase a house price below RM 85,572 and compares to the estimation in Table 4, where the household with income between RM 2,000- RM 3,999 per month are expected to afford buying houses ranged between RM 222,150- RM 247,200 which is far higher that the calculation based on median house price to income ratio formula.

Table 5 Affordable House Price Using Approach PIR

\begin{tabular}{lcc}
\hline Districts & Median Income 2016 (RM) & Affordable Maximum Median House (RM) \\
\hline Bachok & 2,933 per month x 12 months x 3 & 105,588 \\
\hline Kota Bharu & 3, 677 per month x 12 months x 3 & 132,372 \\
\hline Machang & 2,956 per month x 12 months x 3 & 106,416 \\
\hline Pasir Mas & 2,543 per month x 12 months x 3 & 91,548 \\
\hline Pasir Puteh & 2,895 per month x 12 months x 3 & 104,220 \\
\hline Tanah Merah & 3, 021 per month x 12 months x 3 & 108,756 \\
\hline Tumpat & 3, 105 per month x 12 months x 3 & 111,780 \\
\hline Gua Musang & 2, 818 per month x 12 months x 3 & 101,448 \\
\hline Kuala Krai & 2, 541 per month x 12 months x 3 & 91,476 \\
\hline Jeli & 2, 377 per month x 12 months x 3 & $\mathbf{1 1 0 , 8 4 4}$ \\
\hline Kelantan & $\mathbf{3 , 0 7 9}$ per month x 12 months x 3
\end{tabular}

\section{CONCLUSION AND RECOMMENDATION}

It is recommendation that the median house to income ratio to be used to calculatie housing affordability as the price range for affordable homes under the Residual Income and House Cost Burden approach clearly skews to the higher 
housing price when compared to the actual median house price for 2016. Given the simplicity of the 30-percent standard, the house price to income ratio remains a reliable indicator of affordability both over time and across markets. In term of housing affordability in Kelantan, the study concluded that the affordability level among districts varied due to different household income level and housing prices. In term of affordable housing prices, table 5 showed that the 10 districts have different affordable housing prices with Kota Bahru as the main urban centre having higher affordable housing price compare to the other districts.The calculated affordable house price should be use by the Kelantan state government when the state government planned for their housing stock in future.

\section{REFERENCES}

Australian Housing and Research Institute AHURI (2004). Measuring housing affordability. AHURI Research and Policy Bulletin, Brisbane Australia.

Bank Negara: House price growth continues to moderate (2019, March 27). Retrieved from https://www.thestar.com.my/business/business-news/2019/03/27/banknegara-house-price-growth-continues-to-moderate/

Bank Negara Malaysia Annual Report (2016). Demystifying the Affordable Housing Issue in Malaysia. Kuala Lumpur: Bank Negara.

Bertaud, A. (2004). Housing Affordability Rating Categories, Annual Demographia International Housing Affordability Survey. St. Louis Metropolitan Area.

Demographia (2016). 12th annual Demographia international housing survey.

Fox, R., \& Finlay, R. (2012). Dwelling Prices and Household Income. Reserve Bank of Australia (RBA) Bulletin.

GDP by State, 2010-2016. (2017, September 6). Retrieved from Department of Statistics Malaysia, https://dosm.gov.my/v1/ind

Khazanah Research Institute [KRI] (2015). Making housing affordable. Kuala Lumpur: Khazanah Research Institute.

Khazanah Research Institute [KRI] (2016). The state of household. Kuala Lumpur: Khazanah Research Institute.

Leng, T. A. (2018, 28 January). National Housing Policy 2018-2025 aims to combat record property overhang. News Straits Times. Retrieved from: https://www.nst.com.my/content/1465837/national-housing-policy-aimsreconcile-market-mismatch-focus-rent-own-scheme

Maslow's Hierarchy of Needs: Theory of Human Motivation. (2012, June 16). Research History. Retrieved from: http://www.researchhistory.org/2012/06/16/maslowshierarchy-of-needs/

Mohamed Osman, M., Muhamad Yusup, S.W., Abdullah, M. F., \& Shuid, S. (2017). Housing affordability index for districts in Perak. Advanced Science Letters, 23 (7). pp. 6049-6052. 
Mariana Mohamed Osman, Farah Eleena Zainudin, Noor Suzilawati Rabe, Mizan Hitam \& Muhammad Faris Abdullah

An Assessment of Housing Affordability Index at Districts Level in Kelantan

Mohamed Osman, M., Khalid, N., \& Muhammad Yusop, S. W. (2017). Housing affordability in the state of Selangor, Malaysia. Advanced Science Letters, 23 (7). pp. 6188- 6122. ISSN 1936-6612

Mohamed Osman, M., Ramlee, M. A., Samsudin, N., Rabe, N. S., Abdullah, M. F., \& Khalid, N. (2017). Housing affordability in the state of Johor. Planning Malaysia Journal, 15 (1). 347-356.

Pettinger, T. (2019, April 24). How the housing market affects the economy. Retrieved from Economics Help: Helping to Simplify Economics: https://www.economicshelp.org/blog/21636/housing/how-the-housing-marketaffects-the-economy/

National Property Information Centre (NAPIC). (2012). Property Sales Data 2012. NAPIC.

National Property Information Centre (NAPIC). (2014). Property Sales Data 2014. NAPIC.

National Property Information Centre (NAPIC). (2016). Property Sales Data 2016. NAPIC.

Rashdi, A. b. (2017). Bank Negara Malaysia: Statutory Requirements. Kuala Lumpur.

Department of Statistics Malaysia (2016). (2017, October 9). Report of Household Income And Basic Amenities Survey 2016.

Md. Sani @ Abd. Rahim, N. (2015). Price to Income Ratio Approach in Housing Affordability. Journal of Economics, Business and Management, 1190-1193.

Parliament of Australia (2008). A good house is hard to find: Housing affordability in Australia. Canberra: Commonwealth of Australia.

Department of Statistics Malaysia (2017). (2017, July 26). State Socioeconomic Report 2017.

Shuid, S. (2016). The housing provision system in Malaysia. Habitat International, 54 (3), 210-223

Khazanah Research Institute (2015). Making housing affordable. Kuala Lumpur: Author. 